FIU Law Review

Volume 13

Number 1 Environmental Federalism

Article 6

Summer 2018

\title{
Taking the Public out of Public Lands: Shifts in Coal-Extraction Policies in the Trump Administration
}

Jessica Owley

jol@buffalo.edu

Follow this and additional works at: https://ecollections.law.fiu.edu/lawreview

Part of the Administrative Law Commons, and the Environmental Law Commons

Online ISSN: 2643-7759

Recommended Citation

Jessica Owley, Taking the Public out of Public Lands: Shifts in Coal-Extraction Policies in the Trump Administration, 13 FIU L. Rev. 35 (2018).

DOI: https://dx.doi.org/10.25148/lawrev.13.1.6

This Article is brought to you for free and open access by eCollections. It has been accepted for inclusion in FIU Law Review by an authorized editor of eCollections. For more information, please contact lisdavis@fiu.edu. 


\title{
Taking the Public out of Public Lands: Shifts in COAL-EXTRaCTION POLICIES IN THE TRUMP ADMINISTRATION
}

\author{
Jessica Owley ${ }^{*}$
}

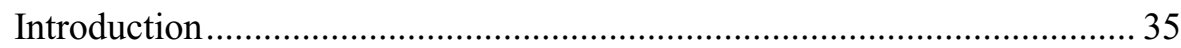

I. Natural Resources Federalism....................................................... 36

II. Natural Resources and the Trump Administration:

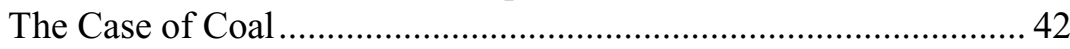

A. Coal-Leasing on Federal Lands ................................................ 42

B. Coal-Leasing Policy Under the Obama Administration ............50 50

C. Trump Administration Coal-Leasing Policy ...............................53 53

III. Natural Resource Federalism and Trumpism .................................. 58

\section{INTRODUCTION}

The election of Donald Trump has brought many surprising and farreaching policy changes. Particularly dismaying has been his attitude towards environmental protection and climate change. He has systematically begun to dismantle environmental protections in favor of business efforts, and this is nowhere so obvious as in his promotion and protection of the coal industry. Indeed, it appears some of his policy initiatives come straight from the hands of coal companies. ${ }^{1}$

Trump campaigned on promotion of coal and extractive industries, and one of the clearest ways he is trying to help those industries is by increasing the amount of land available for resource extraction. To that end, the Administration (largely through the Department of Interior) is working to

\footnotetext{
*Professor, SUNY Buffalo Law School and Profesora Visitante, Universidad Pontificia - Comillas (ICADE). Many thanks to Kalyani Robbins, symposium participants, FIU, and members of the Royalty Committee that shared their experiences with me. My Buffalo colleagues were insightful when I presented part of this research at a faculty workshop. Erin Ryan and Matt Steilen were particularly helpful with the sections on federalism, but should not be blamed for the crudeness of my analysis. Early conversations with Michael Blumm helped shape the essay and inform my larger research agenda, and he deserves my thanks.

1 See Lisa Friedman, Donald Trump Accused of Treating Coal Baron Robert Murray's Wishes for Mining Sector Like a 'To Do List', INDEPENDENT (Jan. 10, 2018), http://www.independent.co.uk/news/world/americas/donald-trump-coal-mining-environmentalregulations-rollback-robert-murray-wish-list-fossil-fuels-a8151556.html (detailing Murray's impressive level of presidential access and influence).
} 
remove environmental protection for lands, shortcut environmental review processes, and facilitate the issuance of mining permits and energy leases. When adopting these policies, the Trump Administration sometimes acknowledges that it is working to promote energy extraction businesses, but also often suggests that changing policy efforts are based on a desire to give states more power in controlling natural resources within their borders. In this way, President Trump can argue that he is working to promote his federalist ideals as a mask for his cronyism. ${ }^{2}$

This essay examines changes in policies regarding coal extraction from the Obama Administration to the Trump Administration. Section I discusses patterns and debates regarding control of natural resource federalism, examining the Trump Administration's platform of shifting more resources to local control. Section II describes federal coal-leasing policy, tracing the efforts begun by the Obama Administration followed by the policy changes being implemented by the Trump Administration. Section III illustrates that the Trump Administration is making resource management decisions from a different perspective compared to earlier presidential administrations, with more benefit focused on business and industry groups than on individuals. As with previous republican administrations, the Trump Whitehouse has announced a policy strongly favoring states' rights and suggests its management decisions are stemming from that principled stance. Spoiler alert: they aren't. The piece concludes by revisiting some of the statutes and principles that underlie the rules for natural resource management to assess whether the Trump Administration is complying with the sentiments that form the basis for the rules. Spoiler alert: it isn't.

\section{NATURAL RESOURCES FEDERALISM}

Federalism is generally the term we use when discussing the delicate (or sometimes not so delicate) balance between federal and state action. A continuous debate in our country surrounds which rights should belong to the states and which to the federal government. The logical starting point for this discussion is the Tenth Amendment, ${ }^{3}$ which tells us that all things not

2 See Heather Long, Trump is a 'Crony Capitalist,' Says GOP Senator Flake, WASH. Post (Aug. 2, 2017), https://www.washingtonpost.com/news/wonk/wp/2017/08/02/trump-is-a-crony-capitalist-saysgop-senator-flake/?utm_term=.3ebedbc7d358; Nomi Prins, The Magnitude of Trump's Cronyism is Off the Charts-Even for Washington, NATION (Dec. 9, 2016), https:/www.thenation.com/article/themagnitude-of-trumps-cronyism-is-off-the-charts-even-for-washington/; Noah Smith, Trump Wants Consumers to Pay for Keeping Coal Alive, BloOMBERG (Oct. 11, 2017), https:/www.bloomberg.com/view/articles/2017-10-11/trump-wants-consumers-to-pay-for-keeping-coalalive.

3 U.S. CONST. amend. X ("The powers not delegated to the United States by the Constitution, nor prohibited by it to the states, are reserved to the states respectively, or to the people."). 
specifically enumerated by the Constitution as belonging in federal hands should be in the realm of state law. Much debate has centered on which branch of government gets the honor of interpreting the Constitution to assess which things belong in the federal realm. ${ }^{4}$

The statement that everything not designated as federal should be left to the states is not as helpful as it may first appear. The truth is that the U.S. Constitution is not as clear of a document as we suggest it to be. Lack of clarity from the Constitution is likely because the problems of today were not contemplated, and the need for precise language was unrealized. ${ }^{5}$

The lack of constitutional clarity is easy to see in the realm of environmental law. Many environmental laws find their constitutional footing in the Commerce Clause (although the Treaty Power and Property Clause have significant roles to play as well). ${ }^{6}$ Yet, the Commerce Clause is confusing, and courts have struggled for years to determine its boundaries. ${ }^{7}$ This leaves a muddy debate over the division between state and federal powers in environmental law.

The patterns of environmental pollution and land degradation in our nation demonstrate why federal policies governing natural resources are often necessary. ${ }^{8}$ For natural resources and land conservation, the concept of environmental federalism is less clear. It is not the environmental federalism that we think about, with the federal government setting the standards and then the states running the program. The relationship is different for a few reasons.

First, while the federal government is the owner of many of the nation's natural resources, resource extraction can feel like a particularly local event. While climate change has global implications, there is no debate that an

4 See, e.g., Erin Ryan, Negotiating Federalism, 52 B.C. L. REV. 1 (2011).

5 Robert H. Bork \& Daniel E. Troy, Locating the Boundaries: The Scope of Congress 's Power to Regulate Commerce, 25 HARV. J.L. \& PUB. POL'Y 849, 851-56 (2002) (discussing early understandings of commerce).

6 Christine A. Klein, The Environmental Commerce Clause, 27 HARV. ENVTL. L. REV. 1 (2003).

7 See Bork \& Troy, supra note 5, at 850-51. Some of the trickiest Commerce Clause cases have involved the Clean Water Act. Robert W. Adler, US Environmental Protection Agency's New Waters of the United States Rule: Connecting Law and Science, 34 FrESHWATER SCI. 1595, 1595-97 (2015) (describing Commerce Clause debates in the context of jurisdiction of the Clean Water Act); Mark Squillace, The Judicial Assault on the Clean Water Act, 59 FED. L. 33, 35-39 (2012) (describing the Supreme Court's Clean Water Act jurisdictional jurisprudence). While the Supreme Court readily acknowledges a federal interest in keeping navigable waters and channels of commerce free from pollution, the Court struggles over how far its interests in waters can stretch. This is a conversation complicated by changing understandings of hydrology and chemistry.

8 See Daniel C. Esty, Revitalizing Environmental Federalism, 95 MicH. L. REV. 570, 590 (1996) (explaining why federal environmental laws are needed); William W. Buzbee, Contextual Environmental Federalism, 14 N.Y.U. ENVTL. L.J. 108, 118 (2005) (explaining how the overlapping federal and state jurisdiction can improve environmental protection). 
action like forest-clearing still has local benefits and drawbacks. The jobs are local. The soil erosion is likely local. The water quality aspects are local or regional. Yet, the biodiversity implications could be global. The climate change impacts are clearly global. Thus, one natural resource extraction decision could affect people and governments at all different levels.

With widespread federal landownership, the issues about responsibility and decision-making power is not hung up on constitutional debates. The Property Clause of the Constitution solidifies the federal government's ability to make all needful rules covering its lands, ${ }^{9}$ and federal courts have consistently interpreted this rule expansively, acknowledging widespread federal powers that can at times extend beyond the boundaries of the public lands. ${ }^{10}$ The status of the federal government as a landowner makes the idea that the federal government has the power to make the rules governing natural resources and environmental conditions on its land logical. I do not suggest the question whether the land should be in federal hands lacks controversy, but once we accept the federal government as landowner, the idea that this landowner gets not only the right to manage its own lands but a superior right to set rules that conflict with state law does not seem like that much of a stretch.

Second, we have a unique legal history with natural resources. Under Roman law, many natural resources were said to be owned by the people. ${ }^{11}$ This included water, ${ }^{12}$ air ${ }^{13}$ wildlife,,${ }^{14}$ and coastal lands. ${ }^{15}$ While title to the resources resided in the people, the government acted as a trustee, protecting and managing these resources on behalf of the citizens. ${ }^{16}$ This concept was translated to British law, with the ownership largely going to the crown but imposing on the king an obligation to safeguard the resources on behalf of present and future generations. ${ }^{17}$ The English kings differed in their interpretation of this duty. As the land and resources of the King of England

9 U.S. CONST. art. IV, § 3, cl. 2.

10 See, e.g., Kleppe v. New Mexico, 426 U.S. 529 (1976); Camfield v. United States, 167 U.S. 518 (1897); Minnesota v. Block, 660 F.2d 1240 (8th Cir. 1981).

11 See Joseph L. Sax, The Public Trust Doctrine in Natural Resource Law: Effective Judicial Intervention, 68 MiCH. L. REV. 473, 475-78 (1970) (discussing the historical foundations of the Public Trust Doctrine).

12 Id. at 475

13 The Institutes of Justinian 2.1.1 at p. 55 (translated Peter Birks and Grant McLeod 1987) ("The things which are naturally everybody's are: air, flowing water, the sea, and sea-shore.").

14 Richard J. Lazarus, Changing Conceptions of Property and Sovereignty in Natural Resources: Questioning the Public Trust Doctrine, 71 IowA L. REV. 631, 640 (1985).

15 Ralph W. Johnson et al., The Public Trust Doctrine and Coastal Zone Management in Washington State, 67 WASH. L. REV. 521, 524 (1992).

16 See Sax, supra note 11.

17 Charles F Wilkinson, The Headwaters of the Public Trust: Some Thoughts on the Source and Scope of the Traditional Doctrine, 19 ENVTL. L. 425, 429-31 (1989). 
in the New World passed to people of the United States after the American Revolution, it was not clear whether the federal government or the state government would serve the role of trustee. ${ }^{18}$ Worry about an overly consolidated federal power, alongside a feeling that the states were closer to the people, meant that the law was generally interpreted as making the state the controller of natural resources.

This leaves us with a muddle. We say it makes the most sense for the states to manage natural resources, but then the federal government is actually the owner of a lot of them, and then we have the pesky problem of natural resources that cross or span state borders making the impacts of natural resource extraction felt at different levels. What is a good federalist to do?

The justifications for federal ownership are many, but here we focus on the idea that the federal government must manage and care for these public trust resources on behalf of all Americans. That is, with public lands and resources, the federal government takes an expansive view of who the public is - going beyond the citizens that directly come in contact with the resources. This broader or longer view combined with a progressive era idea of government officials with expertise in resource management would bring about the greatest good, for the greatest number, for the longest time. ${ }^{19}$

Where the federal government is the landowner, it makes sense that the federal government is the decision maker, as with private landowners. ${ }^{20}$ But such a pattern has not always sat well in regions where the federal government is a large or majority landowner. ${ }^{21}$ In such areas, the states and the citizens of those states may feel that the deck is skewed too heavily in favor of the federal government. This complaint has been particularly

18 Id. at $453-60$.

19 U.S. FOREST SERV., PINCHOT AND UTILITARIANISM, https://www.fs.fed.us/greatestgood/press/mediakit/facts/pinchot.shtml (last visited Dec. 23, 2017) (discussing the letter outlining Gifford Pinchot's theory of management of federal forests as seeking to serve the greatest good for the longest time and the movie that the U.S. Forest Service made to honor the agency's centennial).

20 Camfield v. United States, 167 U.S. 518, 524 (1897) (explaining that the United States has the same power over its land as an ordinary proprietor).

21 See, e.g., Bruce Babbitt, Federalism and the Environment: An Intergovernmental Perspective of the Sagebrush Rebellion, 12 ENVTL. L. 847 (1982) (describing the sagebrush rebellion, a movement against federal landownership and decision-making); Elizabeth M. Osenbaugh \& Nancy K. Stoner, The County Supremacy Movement, 28 URB. LAw. 497 (1996) (describing the County Supremacy Movement and state opposition to federal land ownership); Kirk Siegler, High Stakes As Rancher Cliven Bundy's Trial Over Armed Standoff Begins, NPR (Oct. 30, 2017), https://www.npr.org/2017/10/30/560849871/high-stakes-as-rancher-cliven-bundys-trial-over-armedstandoff-begins (describing the colorful story of the Bundy family that has led armed protests against federal control and regulation of land in the Western United States). 
emotional when it comes to access to natural resources, including oil and gas, minerals, grazing lands, recreation, and hunting. ${ }^{22}$

With clear legal justification for federal regulation of most natural resources, the conversation changes to focus on some combination of efficiency and ethics. Which level of government should be responsible for resource management decisions? ${ }^{23}$ For many states, the issue is neither constitutional language nor economic efficiency, but a more essential debate over the nature of sovereignty and the power of the state to make decisions about the natural resources within its boundaries. The conversation, couched in terms of sovereignty, is undoubtedly economic. For some, the question may be more properly phrased as which entity has the best claim on economic returns from natural resource development?

Patterns of resistance to federal power can come from individuals who want control over resources, like the Cliven Bundys of the world who assert a right to use land owned by the federal government without needing to obtain permission, follow grazing rules, or pay rent. ${ }^{24} \mathrm{We}$ also see more coordinated resistance from state and local governments. ${ }^{25}$ While the federal courts have never decided in their favor, ${ }^{26}$ states routinely pass laws asserting their ownership rights over natural resources and their right to control federal lands. ${ }^{27}$ Although the federal government has made minimal moves to convey lands to states or put them in full control of the resources within their boundaries, the federal agencies sometimes seek state buy-in by including state representatives in management decisions and, importantly, by conveying significant funds to states via PILTs (payments in lieu of taxes) and royalty payments. ${ }^{28}$ And sometimes, the federal government goes the exact opposite direction and ignores state desires. We saw this with President

22 With some people willing to die for their beliefs or willing to kill for them. See, e.g., Robert Anglen, Mohave County Renames Road After LaVoy Finicum, Militia Member Killed by Officers, AZCENTRAL (Nov. 10, 2017, 9:44 PM), https:/www.azcentral.com/story/news/local/arizonainvestigations/2017/11/10/mohave-county-renames-road-after-lavoy-finicum-militia-member-killedofficers/853161001/. We can even date this back to early forest grazing cases. See, e.g., United States v. Grimaud, 220 U.S. 506 (1911) (challenging the Forest Service's ability to regulate grazing on federal lands); see also Light v. United States, 220 U.S. 523 (1911); United States v. Rizzinelli, 182 F. 675 (D. Idaho 1910) (upholding the Forest Service's ability to regulate activity on its land where private individuals had mining permits).

23 See David A. Dana, One Green America: Continuities and Discontinuities in Environmental Federalism in the United States, 24 Fordham ENVTL. L. REV. 103, 103, 107 (2017) (asking those questions generally about environmental law).

24 Siegler, supra note 21.

25 See id.

26 United States v. Gardner, 107 F.3d 1314 (9th Cir. 1997).

27 Ryan McMaken, Can the States Seize Control of Federal Lands?, Mises InstituTE (Aug. 21, 2015), https://mises.org/library/can-states-seize-control-federal-lands.

28 Don Seastone, Revenue Sharing or Payments in Lieu of Taxes on Federal Lands?, 47 LAND ECON. 373 (1971). 
Clinton's designation of Grand Staircase Escalante as a National Monument, where not only was there minimal consultation with officials in Utah but the announcement was made in Arizona. ${ }^{29}$

Is local better? Economists Henry Butler and Jonathan Macey think so. That was the heart of their idea of the Matching Principle, which suggests that decision-making (including resource management decisions) should happen at the level of government where the costs and benefits are most directly felt. ${ }^{30}$ Embodied in their writings is an idea that local is best. Yet, it is hard to determine the costs and benefits (both the amount and who is actually experiencing them) in the context of natural resource management. Often there is a disconnect between costs and benefits. For example, tax dollars from many people support land conservation that most directly benefits those that can see the land or that actually reside on it. The cost is distributed and the benefits concentrated. Alternatively, prohibiting a landowner from converting a wetland to arable farmland, imposes direct pain on her with a benefit felt by large swaths of society who gain water filtration, endangered species protection, and other benefits. These complicated environmental scenarios mean that a simple cost-benefit analysis rarely provides a satisfying outcome.

Determining which level of government is the correct manager of natural resources does not resolve the issue of what the obligations and responsibilities of such management should be. Depending on the level of government, we shift who we regard as the beneficiaries. When the federal government is the trustee, it should be thinking about land management decisions in terms that will yield the greatest benefit for all Americans (hopefully considering both present and future generations). As the level of land management becomes more local, the definition of the beneficiaries narrows to just state residents or, possibly even more devolved, to people in a county or municipality.

The Trump Administration appears to be taking a narrower view of its trustee responsibility than previous administrations. While theoretically the Administration should be acting on behalf of all the current and present generations of Americans, the Department of Interior's actions on natural resource management seem to benefit a smaller subset of the public. Indeed,

29 Paul Larmer, 1996: Clinton Takes a 1.7 Million-Acre Stand in Utah, HiGH CounTry News (Sept. 30, 1996), https://www.hcn.org/issues/90/2795 (describing the anger of Utah officials at the naming of the National Monument). President Trump sharply reduced the size of the monument, a move that does not move the land into private hands but does increase the ability to engage in extractive uses on the land. Julie Turkewitz, Trump Slashes Size of Bears Ears and Grand Staircase Monuments, N.Y. TIMES (Dec. 4, 2017), https://www.nytimes.com/2017/12/04/us/trump-bears-ears.html.

30 Henry N. Butler \& Jonathan R. Macey, Externalities and the Matching Principle: The Case for Reallocating Environmental Regulatory Authority, 14 YALE L. \& POL’Y REV. 23 (1996). 
as the following section will detail, policy changes seem to be targeted at benefitting specific industries or presidential allies.

The following section focuses on one category of natural resource policy in the Trump Administration as a glimpse into the President's view of natural resources federalism. While Trump echoes the federal trust ideas and trumpets states' rights, his decisions appear to be mostly maneuvers to bolster his supporters and donors without regard to general public benefit. I examine changes in policy regarding coal extraction on public lands. To tell this story fully, I explain the coal-leasing program in detail, the Obama Administration's restraints on the program, and the changes coming from the Trump Administration. Along the way, I offer a few other examples that relate to the coal industry and federal environmental and natural resource policy. If the connection between federalism and the current coal policies seems hazy, you are on the right track. The rhetoric of the Administration has been one of supporting state decision-making over the interference of government bureaucrats, but his federalism banner appears to be little more than a smoke screen to justify cronyism. This essay thus offers a brief glimpse into the workings of the Administration and helps us try to align justifications and motivations. ${ }^{31}$

\section{NATURAL RESOURCES AND THE TRUMP ADMINISTRATION: THE CASE OF COAL}

\section{A. Coal-Leasing on Federal Lands}

There are, of course, many different natural resources, and while their management differs, their protection involves similar sentiments because of the scarce nature of the resources and their high societal values. Management can be particularly tricky for resources that are easily depletable or, as with fossil fuels, essentially nonrenewable. In the context of this essay, I examine coal extracted from public land with brief references to other fossil fuels. Through examination of the policy changes, decision-making approaches, and outcomes for coal, we can trace a pattern of approach from the current

31 This coal-leasing example is a small part of a larger research project into the changes in natural resources law occurring under the Trump Administration. Two interesting patterns are emerging. One has to do with how the Administration views natural resources statutes (primarily the Federal Land Policy and Management Act or FLPMA) and who it views as the public beneficiaries of government policy. The second pattern is the federalism story. The Trump Administration and its supporters seem to be mirroring policies of the $1950 \mathrm{~s}$ and $60 \mathrm{~s}$ when states' rights and federalism served as the justification for racist policies. Once again, states' rights are the rallying cry but does not really seem to be the heart of what people making that cry care about. This essay introduces these patterns, but focuses on the second in keeping with the theme of the symposium. 
Administration and perhaps begin to understand the direction of management of all public natural resources in the Trump Administration.

Promotion of the coal industry was an important part of Donald Trump's campaign and has been a cornerstone of his energy policy. ${ }^{32}$ Coal has long been a central component of the U.S. energy supply and has composed significant portions of the nation's electricity grid..$^{33}$ Around $90 \%$ of U.S. coal goes to the electricity market. ${ }^{34}$ Yet, coal's role in U.S. electricity composition is falling. In 1990, coal made up $60 \%$ of the electricity generation in the United States. ${ }^{35}$ By 2016, that percentage had fallen to $32 \%$, taking an $18 \%$ hit from 2015 to $2016 .^{36}$ The reasons for its decline are manifold: (1) a decrease in the overall demand for electricity in the early 2000 s due to the recession coupled with improved energy efficiency; ${ }^{37}$ (2) a decrease in the cost of natural gas based on the rise of hydraulic fracturing technology; ${ }^{38}$ (3) increasing competitiveness of renewable energy sources; ${ }^{39}$ and (4) environmental policies and permitting processes. ${ }^{40}$ Thus, Trump faces the conundrum of trying to uphold a campaign promise to reinvigorate the coal industry that is facing challenges largely beyond his control. It is unsurprising, therefore, that Trump has chosen to focus on reducing costs from environmental policies and looking for other ways to streamline

32 Darryl Fears, Trump Promised to Bring Back Coal Jobs. That Promise 'Will Not Be Kept,' Experts Say, WASH. PosT (Mar. 29, 2017), https://www.washingtonpost.com/news/energyenvironment/wp/2017/03/29/trump-promised-to-bring-back-coal-jobs-that-promise-will-not-be-keptexperts-say/?utm_term $=.5 \mathrm{~d} 0 \mathrm{c} 9 \mathrm{e} 913 \mathrm{f} 58$.

33 U.S. ENERGY INFO. ADMIN., ELECTRICITY IN THE U.S., https://www.eia.gov/energyexplained/index.cfm?page=electricity_in_the_united_states (last visited Dec. 23, 2017).

34 U.S. ENERGY INFO. ADMIN., ANNUAL COAL REPORT 2016 (2017), https://www.eia.gov/coal/annual/ [hereinafter 2016 ANNUAL COAL REPORT] ("The electric power sector accounted for about $92.8 \%$ of the total U.S. coal consumption in 2016.").

35 Christine Klein et al., Wildlife and the Endangered Species Act, in NATURAL RESOURCES LAW, 507 (2018).

362016 ANNUAL COAL REPORT, supra note 34.

37 U.S. Electricity Sales Have Decreased in Four of the Past Five Years, U.S. ENERGY INFO. ADMIN. (Dec. 20, 2013), https://www.eia.gov/todayinenergy/detail.php?id=14291 (explaining that increased energy efficiency is one of the reasons for a decrease in electricity usage and that during the 2009 recession, electricity usage was lower).

38 Charles D. Kolstad, What Is Killing the US Coal Industry?, STANFORD INST. FOR ECON. POL'Y RES. (Mar. 2017), https://siepr.stanford.edu/research/publications/what-killing-us-coal-industry.

39 See Diane Cardwell \& Clifford Krauss, Coal Country's Power Plants Are Turning Away from Coal, N.Y. TiMES (May 26, 2017), https:/www.nytimes.com/2017/05/26/business/energyenvironment/coal-power-renewable-energy.html (discussing industry shifts towards renewable energy technologies).

40 Klein et al., supra note 35, at 508; see also, Jeff Keffer, Excessive EPA Regulations Harming Coal Industry, PARKERSBURG News \& SEnTINEL (Jan. 18, 2017), http://www.newsandsentinel.com/opinion/local-columns/2017/01/excessive-epa-regulations-harmingcoal-industry/ (a coal industry executive expressing his frustration with environmental regulation). 
extraction processes, areas within his control. The Executive Branch can play a significant role in the vibrancy of the coal industry - not only because it enforces many of the environmental regulations at play, but also because it manages significant amounts of the country's coal reserves on behalf of the American people.

When contemplating coal-leasing, two significant bodies of law come into play. First, the coal-leasing laws themselves determine who gets to extract coal from federal lands and the financial arrangements associated with the transactions. These laws operate in conjunction with the general governing rules for the Department of the Interior. Second, federal environmental laws set rules for reducing environmental impacts and conducting environmental review. This section briefly outlines the main federal laws governing the extraction of coal on federal lands. It then explains the Obama-era policies and contrasts them with those of the Trump Administration.

The federal government owns 640 million acres of land, mostly in the West. ${ }^{41}$ In the United States, about half of the coal produced (overall, not just federal lands) is from underground mining that occurs in the eastern half of the country (Appalachia). ${ }^{42}$ This bituminous coal has a high sulfur content. ${ }^{43}$ The other half of the produced coal comes from surface mines in the West on largely federal lands. ${ }^{44}$ This sub-bituminous coal has a lower sulfur content. ${ }^{45}$ The 1990 Amendments to the Clean Air Act meant that many companies switched to the sub-bituminous coal, ${ }^{46}$ putting higher emphasis on the western lands, which were also more likely to be owned by the federal government. ${ }^{47}$ The federal coal-leasing program currently supplies about

41 See Carol Hardy Vincent et al., Cong. Research SerV., R42346, Federal Land OWNERSHIP: OVERVIEW AND DATA (2017), https://fas.org/sgp/crs/misc/R42346.pdf (explaining that the federal government owns "roughly 640 million acres"); Quoctrung Bui \& Margot Sanger-Katz, Why the

Government Owns So Much Land, N.Y. TIMES (Jan. 5, 2016), https:/www.nytimes.com/2016/01/06/upshot/why-the-government-owns-so-much-land-in-the-west.html (describing concentrations of public lands in the West and why that occurred).

42 Lincoln Davies ET AL., ENERGy LAW AND POLICY 107-115 (2015).

43 James C. Hower et al., Changes in the Quality of Coal Combustion By-Products Produced by Kentucky Power Plants, 1978 to 1997: Consequences of Clean Air Act Directives, 78 FuEL 701, 711 (1999).

44 See Nathan Joo et al., Fact Sheet: 5 Things You Should Know About Powder River Basin Coal Exports, CENTER FOR AM. PROGRESS (Aug. 19, 2014, 9:06 AM), https://www.americanprogress.org/issues/green/reports/2014/08/19/95820/fact-sheet-5-things-youshould-know-about-powder-river-basin-coal-exports/.

45 DAVIES ET AL., supra note 42.

46 Byron Swift, How Environmental Laws Work: An Analysis of the Utility Sector's Response to Regulation of Nitrogen Oxides and Sulfur Dioxide Under the Clean Air Act, 14 TUL. ENVTL. L.J. 309, 324 (2001).

47 VINCENT ET AL., supra note 41 (showing concentration of federal land in the western half of the country). 
$40 \%$ of the nation's coal. ${ }^{48}$ Over 570 million acres of federal land is potentially available for coal leasing with the federal government holding either full fee simple title or only the mineral rights. ${ }^{49}$ Most $(85 \%)$ federal coal is from the Powder River Basin in Montana and Wyoming. ${ }^{50}$ In 2014, there were 310 federal coal leases. ${ }^{51}$ In 2015, 383 million tons of coal were produced with federal leases. ${ }^{52}$

The Bureau of Land Management (BLM), within the Department of the Interior, manages the coal-leasing program regardless of which entity manages the surface estate although the most likely federal surface manager is in fact the BLM. ${ }^{53}$ Land under the federal coal-leasing program may also be managed by other federal agencies or owned by other entities (state and local governments as well as private parties). ${ }^{54}$

The first law governing coal extraction on federal lands was the 1872 General Mining Act. ${ }^{55}$ Congress wrote this law in the context of California gold mining, and by the early 1900s, the federal government realized that it

48 RyAN ZINKE, U.S. DEP'T OF THE INTERIOR, SECRETARIAL ORDER No. 3348, CONCERNING THE Federal COAL MORATORIUM 1 (2017) [hereinafter ZinKe ORDER]. Acting Secretary Bail's memo of February 9, 2017, put that number at 42\%. KRISTEN BAIL, BUREAU OF LAND MGMT, U.S. DEP'T OF THE INTERIOR, INFORMATION/BRIEFING MEMORANDUM FOR THE ASSISTANT SECRETARY - LAND AND Minerals Management: InPUT to LEAdERShip on FIVE Promising AREAS FOR CoAl LEASING AND DeVElopment, Production TRENDS, LEASING INFORMATION AND REGULATION/ADMINISTRATIVE Challenges AND OPPORTUNities 2 (2017) [hereinafter BAIL MEMO].

49 See Sally Jewell, U.S. DeP'T of the Interior, Secretarial Order No. 3338, DisCrETIONARY PROGRAMMATIC ENVIRONMENTAL IMPACT STATEMENT TO MODERNIZE THE FEDERAL COAL PROGRAM 1 (2016) [hereinafter JEWELl ORDER].

50 New Powder River Basin-Wide Coal Assessment of Recoverable Resources and Reserves, USGS (Feb. 26 , 2013), https://energy.usgs.gov/GeneralInfo/EnergyNewsroomAll/TabId/770/ArtMID/3941/ArticleID/961/NewPowder-River-Basin-Wide-Coal-Assessment-of-Recoverable-Resources-and-Reserves.aspx.

51 JEWELL ORDER, supra note 49, at 2.

52 BAIL MEMO, supra note 48, at 2.

53 The BLM oversees the leasing process while other entities govern other parts of the process.

See Coal, Bureau OF LAND MGMT., U.S. DEP'T OF THE INTERIOR, https://www.blm.gov/programs/energy-and-minerals/coal (last visited Feb. 20, 2018). States and the Office of Surface Mining Reclamation and Enforcement (OSMRE) have regulatory responsibilities over the operations while the Office of Natural Resources Revenue (ONRR) collects, disburses and verifies revenues from leases and keeps. See Who We Are, OfF. OF Surface Mining Reclamation AND ENFORCEMENT, U.S. DEP'T OF INTERIOR, https://www.osmre.gov/about.shtm (last updated Aug. 10, 2017); Payments, OFF. OF NAT. RESOURCES REVENUE, U.S. DEP'T OF INTERIOR, https://www.onrr.gov/reportpay/payments.htm (last visited Feb. 20, 2018).

54 Coal Data, Bureau OF LAND MgMt., U.S. DEP'T OF THE INTERIOR, https://www.blm.gov/programs/energy-and-minerals/coal/coal-data (last visited Feb. 22, 2018). For the purposes of this essay, we set aside discussion of Indian lands as they are governed by other laws and are associated with a federal trust obligation that does not arise in the context of other lands.

55 See General Mining Act of 1872, ch. 152, 17 Stat. 91 (1872) (codified in scattered sections of 30 U.S.C.). 
was not a good fit for all mineral extraction. ${ }^{56}$ Legislators agreed that they should regulate fossil fuels and other substances (like fertilizers) differently. ${ }^{57}$ This led to the 1920 Mineral Leasing Act. ${ }^{58}$ The 1920 Act instituted a competitive leasing process and, unlike the 1872 Act, contained no provision for transferring lands out of federal ownership. ${ }^{59}$ There were two parts to the program. Alongside the competitive leasing process for known areas of coal resources was a "preference right leasing process" that encouraged private parties to explore and develop coal reserves not yet known. ${ }^{60}$

The coal-leasing program proceeded under this approach until the 1960s when there were concerns about speculation in the coal-leasing market. ${ }^{61}$ By the 1970s, however, government officials became wary of the development of the program. ${ }^{62}$ They worried that prospectors were obtaining permits without diligently pursuing exploration. ${ }^{63}$ Thus, the essential concern was underexploitation (with associated lower revenue generation). This led to the Federal Coal Leasing Amendments Act of $1976 .{ }^{64}$ With this statute, the federal government abandoned the preference rights for not-yet-known sources and created an exclusive competitive leasing process. ${ }^{65}$ Alongside the statute, the Department of the Interior promulgated regulations. ${ }^{66}$ The regulations set minimum royalty rates of $12.5 \%$ for surface mines and $8 \%$ for underground mines. ${ }^{67}$ The regulations also indicated that where mining was to occur on lands managed by the U.S. Forest Service or another land

56 David Gerard, The Development of First-Possession Rules in US Mining, 1872-1920: Theory, Evidence, and Policy Implications, 24 RESOURCES POL'Y 251, 255 (1998).

57 See Robert C. Anderson, Federal Mineral Policy: The General Mining Law of 1872, 16 NAT. RESOURCES J. 601, 613 (1976).

58 See 30 U.S.C. $\S 181$ (2018).

59 As with other natural resources laws of the time, the General Mining Act was a land dispersion act, which sought to facilitate exploitation of federal natural resources and also conveyance of federal lands into private hands. Because miners could work the land without the burden of landownership, many chose not to exercise the ability to patent the land and gain full fee simple title. KLEIN ET AL., supra note 35 .

$60 \quad I d$. at 509.

61 JEWELL ORDER, supra note 49, at 5.

62 KLEIN ET AL., supra note 35, at 509.

63 See Mark Squillace, The Tragic Story of the Federal Coal Leasing Program, 27 NAT. RESOURCES \& ENV'T 29, 30 (2013).

64 Federal Coal Leasing Amendments Act, H.R. 6721, 94th Cong. (1976); see Sam Kalen, Where Do We Go From Here?: The Federal Coal Leasing Amendments Act-Past, Present, and Future, 98 W. VA. L. REV. 1023, 1024-25 (1995).

65 See Cedric Hustace, The New Federal Coal Leasing System, 10 NAT. RESOURCES LAW 323, 359 (1977).

66 See 43 C.F.R. $\S \S 3420-3470$ (2018).

6743 C.F.R. $\S 3473.3-2$ (2018). 
management entity, that agency's consultation and approval is required. ${ }^{68}$ Consultation with states and Indian tribes is also required before land can be opened to leasing. ${ }^{69}$

Also, in 1976, Congress passed the Federal Land Policy and Management Act (FLPMA). ${ }^{70}$ This statute serves as the organic act for the BLM, outlining its duties and giving details about its methods of operation. ${ }^{71}$ BLM studies in the 1970s showed that the number of acres under production increased while the levels of coal production actually fell. ${ }^{72}$ The BLM responded by placing a moratorium on coal-leasing while engaging in an environmental review under the 1969 National Environmental Policy Act (NEPA). ${ }^{73}$ The process resulted in a programmatic environmental impact statement, a comprehensive environmental review for the program as a whole, followed by NEPA litigation, and eventually new leasing regulations (that were again subject to litigation). ${ }^{74}$ These leasing regulations - the 1979 coal-leasing regulations with amendments in 1982 - are the ones that still govern operations today. The moratorium implemented during the environmental review process was gradually scaled back and fully lifted in $1981 .^{75}$

In 1981, concerns regarding the calculation of fair market value in the Powder River Basin reared their ugly heads. ${ }^{76}$ This led to the establishment of the Linowes Commission in 1983 to investigate pricing. ${ }^{77}$ The Commission imposed another moratorium on leasing while conducting an environmental study ${ }^{78}$ That moratorium was lifted in $1987 .{ }^{79}$ Unfortunately, these reviews did not seem to alleviate the underlying pricing and competition concerns.

\footnotetext{
6843 C.F.R. $\S \S 3420.1-6,3420.4-2$ (2018).

69 See 43 C.F.R. $\S \S 3420.1-7,3420.4-3,3420.4-4$ (2018).

70 Federal Land Policy and Management Act of 1976, Pub. L. No. 94-579, 90 Stat. 2743.

71 Frank Gregg, Symposium on the Federal Land Policy and Management Act: Introduction, 21 ARIZ. L. REV. 271, 271 (1979).

72 Jewell Order, supra note 49, at 5; see Robert H. Nelson, The Making of Federal CoAl POLICY 25 (1983); Squillace, supra note 63, at 30.

73 See John Latz, The Federal Coal Leasing Program, PuB. LANDS MIN. LEASING: Issues AND DiRECTIONS 1 (1985).

74 See Bureau of Land Mgmt., U.S. Dep'T Of the InTERIor, Final EnVIronmental ImPaCt Statement Supplement for the Federal Coal Management Program 4 (1985) (explaining that NEPA process from 1979-1985).

75 JEWELL ORDER, supra note 49 at 5, 6.

76 Id. at 6; Squillace, supra note 63, at 30.

77 Sandra L. Blackstone, Getting the Coal Leasing Program Back on Track: The Linowes Commission and Beyond, in PuB. LANDS Min. LeAsing: Issues AND Directions 1, 5 (1985).

78 JEWELL ORDER, supra note 49, at $\S 2$ (c).

79 Id.
} 
The 1979 regulations establish two avenues for leasing. One is where the BLM reviews an area of land and designates zones as open for bidding (regional leasing). ${ }^{80}$ The other is where the members of the public (i.e. energy/extraction companies) file applications to open an area to extraction (leasing by application). ${ }^{81}$ The regional system was only briefly used in the 1980 s, and since then, all coal-leasing has occurred by application. ${ }^{82}$ This is true despite the fact that regional leasing is supposed to be the default process and leasing by application only to occur in unusual circumstances. ${ }^{83}$

If you seek to mine coal on federal land today, you must proceed through a somewhat lengthy but relatively straightforward process. The first step is to identify an area you want to mine and ask the BLM to open it up for competitive bidding. ${ }^{84}$ The BLM assesses the land and determines whether it should be opened for coal-leasing. The BLM reviews the application to make sure it is complete, conforms to existing land-use plans, and contains enough information to determine the fair market value of the coal. ${ }^{85}$ It then begins the environmental review process ${ }^{86}$ and consults with landowners, states, tribes, and other stakeholders. ${ }^{87}$ It also checks to see whether the surface owner will consent. ${ }^{88}$ Note, because the mineral estate is considered the dominant estate, holders of the mineral estate have a right to extract the subsurface minerals even where such extraction may impact the owners of the surface estate. ${ }^{89}$

After or in conjunction with public commenting, the BLM estimates the fair market value of the coal..$^{90}$ It keeps that information confidential while opening the area for bidding (thus, the initial application is just to allow bidding on a certain parcel, but the entity filing the application will not necessarily end up with the lease). Bids are accepted, and the winning bid is

8043 C.F.R. $\S 3420$ (2014).

81 Id. at $\S 3425$.

82 JEWELL ORDER, supra note 49, at $§ 2(a)$.

83 Squillace, supra note 63 , at 3.

84 There is also a process for opening up new areas under non-competitive bidding, through a lease by modification process. Under the lease by modification process, an existing leaseholder can request to have a tract added but must demonstrate that it would not be of competitive interest. That is, but for the applicant, the mineral resources would not be exploited. BAIL MEMO, supra note 48, at 2.

85 JEWELL ORDER, supra note 49, at $\S 2$ (a).

86 The question of when to conduct NEPA review in the context of coal mining has been a fraught topic since the 1970s. KLEIN ET AL., supra note 35, at 120-132.

87 JEWELL ORDER, supra note 49, at $§ 2$ (a). This stage could also involve actions under Section 7 of the Endangered Species Act or review under Section 106 of the National Historic Preservation Act. See 16 U.S.C.A. $§ 1536$ (West 2004); 54 U.S.C.A. § 306108 (West 2014).

88 JEWELL ORDER, supra note 49, at $\S 2$ (a).

89 Kendor P. Jones et al., Split Estates and Surface Access Issues, in LANDMAN's LEGAL HANDBOOK 193-95 (5th ed. 2013).

9043 C.F.R. $\S 3422.1$ (b) (2014). 
the highest one received but cannot be lower than the fair market value. ${ }^{91}$ This means that there could be a failed bidding process if none of the bids received matches the fair market value estimated by the BLM. Bidders must meet eligibility requirements and pay certain fees. ${ }^{92}$ Bids contain a proposal for royalty payments, rental payments, and an initial payment. ${ }^{93}$ By regulation, the royalty payments cannot be under $12.5 \%$ for surface mines or under $8 \%$ for underground mines. ${ }^{94}$ In theory, bidders could offer more in an attempt to be the winning bid, but this rarely happens. This is likely because in over $90 \%$ of the leases, there is only one bidder - the person who initiated the process to begin with. ${ }^{95}$

Once a company has won the bid, it has to get a permit under the Surface Mining Control and Reclamation Act of 1977 (SMCRA), and it has to obtain approval of a federal mine plan from the Assistant Secretary for Land and Minerals. ${ }^{96}$ The BLM receives money in three ways: (1) bonus paid at the time of lease issuance, (2) rental fees, and (3) production royalties. ${ }^{97}$ All three sources of money are split evenly with the state. ${ }^{98}$ This gives states a financial incentive to not only increase mining overall but also to increase royalty and rent levels. This may be particularly so where the subsurface and surface are both held by the federal government because there is no competing interest coming from the surface owner. This reveals the state motivation for encouraging coal-leasing. ${ }^{99}$ The activity occurs on federal land, but the state gets half the money. ${ }^{100}$

\footnotetext{
91 Id. at $\S 3422.1$ (c)(1); JEWELL ORDER, supra note 49, at $\S 2$ (a).

9243 C.F.R. § 3472.1-1 (2014).

93 JEWELL ORDER, supra note 49, at § 2(a).

9443 C.F.R. $\S \S 3473.3-2(a)(1)-(2)$ (2014).

95 JEWELL ORDER, supra note 49, at § 2(b)(i).
}

96 The major environmental laws at play are the National Environmental Policy Act (NEPA) and the Surface Mining Control and Reclamation Act of 1977 (SMCRA). 42 U.S.C. $\S \S 4321-4375$ (2016); 30 U.S.C. $\S \S 1201-1328$ (2016). NEPA requires environmental review for federal actions that may significantly affect the environment. SMCRA requires a permit for any coal-mining operations regardless of whether on public or private land. The issuance of a SMCRA permit triggers NEPA so a NEPA process is required for all coal operations in the United States.

97 JEWELL ORDER, supra note 49, at $§ 2(a)$.

98 Squillace, supra note 63 , at 3.

99 However, even under this scenario, a state should be motivated to improve the competitive nature of the bids or set minimum bidding levels as current bids appear to be well below market. Id. at 4 5 .

100 See, e.g., Bill Chappell, U.S. Announces Moratorium on New Coal Leases on Federal Lands, NPR (Jan. 15, 2016, 9:40 AM), https://www.npr.org/sections/thetwo-way/2016/01/15/463164790/u-smoratorium-on-new-coal-leases-to-be-announced-friday (stating that in 2014, Wyoming received over \$555 million from federal coal leases). 


\section{B. Coal-Leasing Policy Under the Obama Administration}

After years of concerns with the federal coal-leasing program from multiple fronts, the Secretary of the Interior in the Obama Administration, Sally Jewell, called for an "open conversation about modernizing the [ ] coal program." 101 Also inspiring action were reports completed by the Office of the Investigator General (OIG) and the Government Accountability Office (GAO). ${ }^{102}$ These reports (the "OIG/GAO Reports") expressed concern with whether taxpayers were actually receiving fair market value from the sale of coal. ${ }^{103}$ The reports noted problems with a lack of transparency, ${ }^{104}$ and their findings on absence of competition suggested an oversupply of coal. ${ }^{105}$

The Department of the Interior began a series of listening sessions in 2015. ${ }^{106}$ The five listening sessions involved hundreds of attendees and 289 speakers. ${ }^{107}$ Over 92,000 comments were submitted. ${ }^{108}$ The comments identified six themes of concern: (1) global climate change, ${ }^{109}$ (2) loss of jobs and revenue, (3) need for increased transparency and public participation plus concerns over inadequate compensation, (4) the royalty rate (both the idea that it needs to account for environmental costs and that it should match offshore extraction), (5) need to keep rates low (and even make them lower), and (6) streamlining of the leasing process. ${ }^{110}$

101 Bureau of Land Mgmt., U.S. Dep't of the Interior, 1 Federal Coal Program Programmatic EnVironmental IMPACt StATEMENT-SCOPING REPORT ES-3 (Jan. 2017) [hereinafter PEIS SCOPING REPORT].

102 U.S. Gov'T ACCOUNTABILITY OfFice, GAO-14-140, COAL LEASING: BLM COULD ENHANCE Appraisal Process, More Explicitly Consider CoAl Exports, and Provide More Public INFORMATION (2013) [hereinafter GAO REPORT]; OFFICE OF THE INSPECTOR GEN., U.S. DEP'T OF INTERIOR: REPORT No. CR-EV-BLM-0001-2012, Final EVAluation REPORT - COAL MANAGEMENT PROGRAM (2013) [hereinafter OIG REPORT].

103 GAO REPORT, supra note 102, at 15-17; OIG REPORT, supra note 102, at 1.

104 GAO REPORT, supra note 102, at 47.

105 Benjamin Storrow, Moratorium Announced on New Coal Leases, CASPER STAR TRIB. (Jan. 15, 2016), http://trib.com/business/energy/moratorium-announced-on-new-coal-leases/article_5342a826cacd-5120-9e6a-23cfee3c865f.html.

106 PEIS SCOPING REPORT, supra note 101, at 2-2.

107 JEWELL ORDER, supra note 49, at § 2(b).

108 PEIS SCOPING REPORT, supra note 101, at 2-2.

109 Under the Paris Agreement, the Obama Administration pledged to reduce emissions to 26$28 \%$ below 2005 levels by 2025 . There is no current mechanism in the coal-leasing process that considers climate change impacts or seeks to reduce them. A potential exception comes from the recent Tenth Circuit decision in WildEarth Guardians v. U.S. Bureau of Land Mgmt., where the court held that the BLM must consider greenhouse gas emissions in its NEPA review. 870 F.3d 1222, 1228-1229, 1240 (10th Cir. 2017); Court Defends Climate Overturns Massive Coal Mining in Wyoming, WiLdEARTH GuARDIANS (Sept. 15, 2017), http://www.wildearthguardians.org/site/News2?page=NewsArticle\&id=13190\#.Wz7bLthKjfY (on file with author).

110 JEWELL ORDER, supra note 49, at § 2(b). 
The problems related to fair return present a complicated economics puzzle. A 2014 BLM manual and guidebook provided policy guidance (note this is agency guidance and not binding law) regarding calculation methods for the fair market value of coal leases. ${ }^{111}$ Unfortunately, there are very few bids in the process, making it hard to estimate the fair market values. ${ }^{112}$ The process also fails to account for externalities in setting the fair market value. ${ }^{113}$ Additionally, although regulations set minimum royalty rates, royalty rates may go below the mandated minimum where an applicant seeks a lease modification or applies for a royalty-rate reduction. ${ }^{114}$ Studies showed that these practices were prevalent. ${ }^{115}$ There is a minimum bonus rate, of $\$ 100$ per acre, which some have labeled ridiculous. ${ }^{116}$

In January 2016, Secretary Jewell issued Secretarial Order 3338. ${ }^{117}$ The order announced a programmatic environmental review of the coal-leasing program alongside what it labeled a "pause" in issuing new coal leases during the pendency of the review process. ${ }^{118}$ The ten-page order begins by explaining the purpose of the Secretary's actions, stating that the Department of the Interior is entrusted with overseeing federal resources for the "benefit of current and future generations." 119 The Secretary asserted that doing so involved advancing a "safe and responsible development of energy" while also considering conservation, scientific, historical, and environmental values "for generations to come." ${ }^{20}$ Secretary Jewell pointed out that the governing regulations for coal leasing dated back to 1979, when our understanding of environmental impacts and the contours of the coal industry

111 Bureau of Land Mgmt., U.S. DeP’T of the InTERior, H-3070-2, ECONOMIC EVAluation OF OIL AND GAS PROPERTIES HANDBOOK.

112 JEWELL ORDER, supra note 49, at § 2(b)(i).

$113 \quad I d$

$114 \quad I d$

$115 \mathrm{Id}$

11643 C.F.R. $\S 3473$ (2014); Stephen Lacey, Noncompetitive Coal Leasing Policies Cost U.S. Taxpayers \$29 Billion Since 1982, THINK PROGRess (June 25, 2012, 8:18 PM), https://thinkprogress.org/noncompetitive-coal-leasing-policies-cost-u-s-taxpayers-29-billion-since-19822ebc6ae6a957/; see also Ben Jervis, Subsidized to the End: Not Even Corporate Welfare Can Save Big Coal, Huffington POst (Mar. 31, 2016, 2:35 PM) https://www.huffingtonpost.com/benjervey/subsidized-to-the-end-not_b_9554742.html; JAYNI FOLEY HEIN \& PETER HOWARD, Reconsidering Coal's Fair Market Value: The Social Costs of Coal Production and the $\begin{array}{llllll}\text { NEED } & \text { FOR } & \text { FISCAL } & \text { REFORM } & 8 & \text { (2015), }\end{array}$ http://policyintegrity.org/files/publications/Coal_fair_market_value.pdf.

117 The review was about the leasing of the federal mineral estate and contained exceptions for Indian lands and actions by OSMRE and ONRR. See generally JEWELL ORDER, supra note 49.

118 See id. at $\S 5$.

119 Id. at $\S 1$.

$120 \mathrm{Id}$ 
were far different from what we encounter today. ${ }^{121}$ Based on these factors, she directed the BLM to prepare a Programmatic Environmental Impact Statement (PEIS), ${ }^{122}$ something that had last been done in the 1970 s. ${ }^{123}$

In explaining her authority for choosing to do a "discretionary PEIS," Secretary Jewell noted that the Department of Interior is authorized to undertake the effort based on:

[I]ts stewardship role as a proprietor and sovereign regulator which is charged by Congress with managing and overseeing mineral development on public lands not only for the purpose of ensuring safe and responsible development of mineral resources, but also to ensure conservation of the public lands, the protection of their scientific, historic, and environmental values and compliance with applicable environmental laws. ${ }^{124}$

These sentiments and those mentioned above mirror the purposes of the public lands as articulated by Congress in the Federal Land Policy and Management Act (FLPMA). ${ }^{125}$ Secretary Jewell further explained the decision to conduct a PEIS as a statutory duty to ensure a fair return to the taxpayer. ${ }^{126}$ She invoked 1920 Mineral Leasing Act, SMCRA, and FLPMA. ${ }^{127}$

Instead of calling it a moratorium, she labeled her action a "pause" on the issuance of new federal leases. ${ }^{128}$ As coal leases last over twenty years, she felt it was appropriate to determine the impacts and faults with the current system before entering into long-term agreements. ${ }^{129}$ She highlighted that her pause on issuing leases is standard procedure followed by the BLM when assessing the coal-leasing program. ${ }^{130}$

Shortly after Secretary Jewell's order, the BLM began the process for completing the PEIS. The first step of a NEPA review is the scoping process where the agency in charge of the NEPA review determines the contours of the review and the variety of alternatives that will be considered in the final

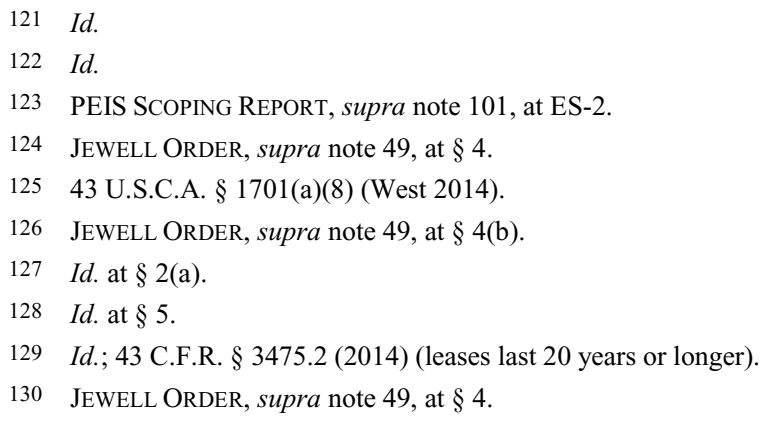


document. ${ }^{131}$ As part of the scoping process, the BLM received input from over 500 speakers at six public scoping meetings. ${ }^{132}$ The BLM issued its scoping report on January 11, 2017..$^{133}$ The report concluded that modification of the federal coal-leasing program was warranted and instructed the PEIS to focus on fair returns, climate change, resource management and protection, and improved program administration. ${ }^{134}$

\section{Trump Administration Coal-Leasing Policy}

Coal leasing on public lands has had a renewed life under the Trump Administration. ${ }^{135}$ Once President Trump came into office, the Department of the Interior began by assessing the coal-leasing program through two memos. The first was completed by acting BLM director Kristin Bail on February 9, 2017. ${ }^{136}$ The Bail memo had five purposes: "(1) identify the most promising areas for coal leasing and development, (2) report on how much coal mining is happening and where it is happening, (3) describe current regulator activity, (4) identify the coal companies still in business, and (5) determine how the BLM could spur coal mining." 137

13140 C.F.R. $\S 1501.7$ (2014); James TB Tripp \& Nathan G. Alley, Streamlining NEPA's Environmental Review Process: Suggestions for Agency Reform, 12 N.Y.U. ENVTL. L.J. 74 (2003).

132 In this scoping process, the BLM received 214,886 comments $-1,118$ of which were unique. There were also three external workshops that were held at universities. MichAEL NEDD, BuREAU OF LAND Mgmt., Recommendation to Revoke Order 3308, (Mar. 28, 2017) (on file with author) [hereinafter NEDD MEMO].

133 See generally PEIS SCOPING REPORT, supra note 101.

134 NedD MEMO, supra note 132, at 1.

135 Eric Lipton \& Barry Meier, Under Trump, Coal Mining Gets New Life on U.S. Lands, N.Y. TIMES, Aug. 7, 2017, at A1.

136 Bail was named Acting Director early in 2017 when her predecessor Neil Kornze stepped down with the coming of the new administration. She had long worked for the BLM and other federal and state resources agencies. She served only a few months before Michael Nedd was named Acting Director in March 2017. He lasted until November 2017. Nedd had previously been acting director of the BLM's Office of Energy and Minerals, and his selection was seen as a move to strengthen the role of energy extraction on federal lands. Thomas Burr, Interior Names Energy and Mineral Chief New Acting BLM Director, SALT LAKE TRIB. (Mar. 15, 2017), http://archive.sltrib.com/article.php?id=5062376\&itype=CMSID. As of this writing, Brian Steed, BLM's Deputy Director for Programs and Policy, is exercising authority of the director. Leadership Overview, BUREAU OF LAND MGMT., https://www.blm.gov/leadership (last visited Feb. 28, 2018); see Dino Grandoni, The Energy 202: New 'Acting Director' at Interior Office Worries Public Lands Advocates, WASH. POST (Nov. 20, 2017), https://www.washingtonpost.com/news/powerpost/paloma/the-energy202/2017/11/20/the-energy-202-new-acting-director-at-interior-office-worries-public-lands-

advocates/5a12341f30fb045a2e00325c/. As of April 2018, Trump had not yet nominated a new director. The Federal Vacancies Reform Act of 1998 allows the president to name acting directors who generally serve for no more than 210 days. 5 U.S.C.A. § 3345-46 (West 2014).

137 BAIL MEMO, supra note 48, at 1. Notice that the tone of the questions assumes that one wants to promote mining. Despite the moratorium, the BLM was not discussing whether coal mining should be developed, but how best to do so. 
In her memo, Acting Director Bail described the five areas with the best coal potential on federal lands and unsurprisingly, number one was the Powder River Basin, where most coal extraction currently occurs. ${ }^{138}$ She also explained that the Powder River Basin used to have a separate regulatory requirement relating to a Regional Control Team, an independently functioning advisory board made up of federal and state officials. ${ }^{139}$ The BLM and lease applicants had to consult with (and defer to) the team in deciding whether a particular coal lease should be processed in a public forum. The Bail memo specifically responded to the OIG/GAO Reports from 2013 that audited the coal-mining process. ${ }^{140}$ Those reports included twentyone recommendations. ${ }^{141}$ Bail stated that all of the recommendations were corrected to the satisfaction of $\mathrm{OIG}$ and $\mathrm{GAO}$, and the inquiries from those organizations are now closed. ${ }^{142}$

Bail noted that most actions that could help spur the coal industry are beyond the BLM's control. ${ }^{143}$ But in looking for some action that would be within its purview, she suggested streamlining some of the permit processes, removing the Regional Control Team as redundant with other policies (such as the NEPA process), and lifting the coal-leasing moratorium. ${ }^{144}$ While some had suggested few coal companies would be interested in filing new lease applications, as of February 2017, the BLM was processing twenty-eight applications for initial leases and sixteen applications for leases by amendment. ${ }^{145}$ At the time of Bail's memo, seven (of the forty-four) were on hold due to economics. ${ }^{146}$ The memo also recommends higher staffing levels for NEPA compliance as well as removing and updating policies, models, and manuals, some of which date back to the 1980s. ${ }^{147}$

A little over a month later, with new Acting Director Michael Nedd at the helm, the Trump Administration released a second memo recommending the revocation of the coal-leasing moratorium. ${ }^{148}$ While the reasoning for switching Acting Directors was not publicly explained (and at the time of this

138 Other sites were the Unita-Piceance Basin, Green River Basin, San Juan Basin, and areas of Oklahoma and North Dakota. Id. at 2.

139 Id. at 3.

140 Id. at 1.

141 Id.

$142 I d$.

143 Id. at 3.

144 Id. Interestingly, Bail calls it a pause and not a moratorium, potentially based on her longer time working at the BLM and her use of the common intra agency terminology.

145 Id. at 2.

146 Id.

147 Id. at 4-5.

148 Nedd MEMO, supra note 132, at 1. 
writing, we are on Acting Director number three with Brian Steed) ${ }^{149}$ the elevation of Nedd was likely specifically to explore the development of energy on public lands. ${ }^{150}$

Tasked with developing energy on public lands, Nedd quickly released his own memo. In it, he recounted the current progress of the NEPA review. ${ }^{151}$ His analysis of the PEIS scoping report (which stated that review of the coal-leasing program was warranted) concluded that a PEIS is not warranted. ${ }^{152}$ Acknowledging that some reforms might be desirable, the Nedd memo concluded that a PEIS is not necessary to make needed reforms, instead suggesting a BLM program review that would not involve a NEPA process or a moratorium on coal leasing. ${ }^{153}$ Nedd also stated that it was not sensible to wait for the completion of the NEPA process because the BLM could not possibly complete the PEIS by its initial deadline. ${ }^{154}$

Nedd acknowledged the concerns with receiving a fair return for the nation's coal. ${ }^{155}$ While the law requires a fair return, it offers no definition of how to determine what is fair. For example, the BLM is not certain as to whether it should be accounting for externalities or using a "carbon adder" to calculate the appropriate minimum bids. ${ }^{156}$ This issue has been a topic of conversation for years, Nedd pointed out, including in the $2013 \mathrm{OIG} / \mathrm{GAO}$ reports. ${ }^{157}$ However, the OIG and GAO have since given the BLM the green light, and the BLM has already implemented several changes, for example,

149 As Nedd's appointment was seen as a decision to focus on energy development, arguably Steed's appointment is a shift towards a program of shrinking monuments and transferring public lands, things he has advocated for in the past. It is also notable that instead of elevating someone who had been a BLM employee for many years, this time Secretary Zinke named someone with greater ties to the states (specifically Utah) than to the federal government. Secretary Zinke Names Land Transfer Proponent as Acting Director of The Bureau of Land Management, CENTER FOR W. PRIORITIES, (Nov. 16, 2017), $\mathrm{http}: / /$ westernpriorities.org/2017/11/16/secretary-zinke-names-land-transfer-proponent-as-actingdirector-of-the-bureau-of-land-management/.

150 In a statement at the time, Interior Secretary Ryan Zinke said, "Let me make one thing clear, the Interior Department is in the energy business and Mike is an energy guy who understands the balance we must strike when developing resources and creating jobs on our public lands." Thomas Burr, supra note 136; Scott Streater, BLM's “Energy Guy" May Signal the End of Big Renewables, E\&E NEWS, (Mar. 31, 2017), https://www.eenews.net/stories/1060052439.

151 NeDD MEMO, supra note 132, at 1.

152 Id. at 2.

153 Id. (stating that NEPA review is not the appropriate vehicle to analyze possible reforms because BLM has its own review process already examining these issues).
154 Id.
155 Id. at 3.
156 Id. at 3-4.
157 Id. at 3. 
improving reports, accounting, and public access to documents. ${ }^{158}$ The BLM has also already made changes to the bonus bidding process. ${ }^{159}$

These memos provided the background for the Trump Administration's secretarial order on coal leasing. On March 29, 2017, Secretary of the Interior Ryan Zinke revoked the pause, ending the moratorium on issuance of coal leases. ${ }^{160}$ The purpose of the moratorium's repeal was economic. Specifically, the order lifting the ban states that due to "the critical importance of the Federal coal leasing program to energy security, job creation, and proper conservation stewardship" the Administration was removing the ban. ${ }^{161}$ Zinke seemed particularly concerned with the length and cost of the environmental review process (which he described as costing "many millions of dollars" with completion "no sooner than 2019"). ${ }^{162}$ Thus, not only did the new policy lift the ban on coal leasing, it also halted the process of environmental review while suggesting that the Administration would still be considering potential improvements to the Federal Coal Program. ${ }^{163}$

While the Zinke memo lists conservation stewardship as one of the motivations for revoking the moratorium, it offers no explanation of how such a move would be working to improve or protect conservation interests. Secretary Zinke based his decision on information from the previous executive order, the scoping process, and "other information provided by BLM." 164 The secretarial order describes the decision as "consistent with the principles of responsible public stewardship entrusted to this office."165

With the pause now on the NEPA process, instead of on the issuance of coal leases, the Administration looked to different tools to seek improvements and participation in coal leasing. ${ }^{166}$ Thus, in September 2017, the Trump Administration created an advisory committee on coal leasing. A

158 Id. at 4.

159 Id.

160 ZINKE ORDER, supra note 48, at 1.

161 Id.

162 Id.

163 Id.

164 Id.

165 Id.

166 Whether we consider the NEPA process to be paused or completely halted depends on whether you think courts (or future administrations) will restart the process. Secretary Zinke declared the NEPA process over. $I d$. at 2 . Several environmental groups filed suit in the wake of this announcement, and a court could potentially require further NEPA review. See, e.g., Complaint for Declaratory and Injunctive Relief at 4, Citizens for Clean Energy v. Dep't of Interior, No. 4:17-CV-00030 (D. Mont. Mar. 29, 2017). Additionally, a different presidential administration may seek to recommence NEPA review. Depending on the timing and conditions of the coal industry, future NEPA processes may be able to use the alreadycompleted Scoping Report or a new Scoping Process may need to begin. 
Department of Interior press release described this move as a "significant step toward restoring public trust." 167 The Department of the Interior suggests that the process will modernize land management while building greater trust and transparency, describing a main goal of the process as ensuring that both taxpayers and Native American tribes get the "full and fair value" of their energy resources. ${ }^{168}$ The language is couched in economic terms with a focus on extraction of value from natural resources. Indeed, although the Department suggests a wide-ranging committee would examine various aspects of coal leasing, the group is named the "Royalty Policy Committee." 169 Furthermore, its official objectives focus on calculating fair market value of resources and ensuring the "public receives the full value of the natural resources produced from Federal Lands." 170

The committee is chaired by Vincent DeVito, an attorney specializing in regulatory issues and government affairs. ${ }^{171}$ The committee has an equal number of state and industry members (six each) along with four representatives each from tribes and academia. ${ }^{172}$ Not all states are represented. Not all tribes are represented. Eight different federal agencies also send representatives. ${ }^{173}$ There are no nonprofit organizations; notably, there are no environmental groups. At the first meeting in October 2017, the group formed three subcommittees: (1) Subcommittee on Fair Return and Revenue, (2) Subcommittee on Planning, Analysis, and Competitiveness, and (3) the Subcommittee on Indian Affairs. ${ }^{174}$ It is not clear whether the planning committee will consider environmental issues and there has not been a suggestion that the fair return committee will consider externalities.

167 Press Release, Secretary Zinke Appoints Members to the Royalty Policy Committee, Announces First Meeting, U.S. DEP'T OF THE INTERIOR (Sept. 1, 2017), https://www.doi.gov/pressreleases/secretaryzinke-appoints-members-royalty-policy-committee-announces-first-meeting. The group had its first meeting on October 4, 2017.

$168 I d$

169 U.S. DeP'T OF THE INTERIOR, ROYAlty POLICy COMMitTeE Charter 1 (2017), https:/www.doi.gov/sites/doi.gov/files/uploads/2017_charter_royalty_policy_committee.pdf [hereinafter Royalty POLICY COMMitTEe CHARTER].

170 Id.; Press Release, Secretary Zinke Appoints Members to the Royalty Policy Committee, Announces First Meeting, U.S. DEP'T OF THE INTERIOR (Sept. 1, 2017), https:/www.doi.gov/pressreleases/secretary-zinke-appoints-members-royalty-policy-committeeannounces-first-meeting.

171 Confidential Interview with a Committee Member.

172 Id.

173 See RoyAlty POLICY COMMITTEE CHARTER, supra note 169, at 2.

174 Press Release, Readout of the First Meeting of Re-chartered U.S. Interior Royalty Policy Committee, U.S. DEP'T OF THE INTERIOR (Oct. 4, 2017), https://www.doi.gov/pressreleases/readout-firstmeeting-re-chartered-us-interior-royalty-policy-committee. 
While there are complaints about transparency, committee meetings are open to the public and available online. ${ }^{175}$

These movements from the Trump Administration leave us with a coalleasing program governed by regulations and royalty rules from the 1970s, operations without environmental review, and a stated intention to continue evaluating the coal-leasing program while still issuing leases under the old system. The progress on such re-evaluation is uncertain. The only clear process at the time of this writing is the advisory committee, which even committee members view as ineffectual.

\section{NATURAL RESOURCE FEDERALISM AND TRUMPISM}

With a basic understanding of the tenets of federalism in the natural resources context from section II and a detailed understanding of the federal coal-leasing process in section III, we can now contemplate how the coalleasing process fits into the federalism ideals of the current Administration.

Concerns about the federal coal-leasing process and its potential for only benefiting a small section of society are not new. We have over fifty years of critiques regarding the issuance of leases and calculation of fair market value. We have over thirty years of concerns regarding environmental and health impacts of coal leasing. On some topics, the Obama and Trump Administrations seem to be focusing on repairing similar troubles. Both administrations acknowledge a need for comprehensive review of the federal coal program to help ensure taxpayers receive a fair return on the value of the natural resources. There is marked disagreement, however, in how to go about remedying these agreed-upon problems and in who gets to participate in the decision-making process. The Obama Administration called for a lengthy, time-consuming, and expensive review process. For the three years that Interior officials anticipated the review taking, they placed a moratorium on issuing new leases. In the early phases of that process, we saw high levels of public information and public involvement, with many descriptive orders and background reports. The process included participation of different stakeholders including tribes, states, energy companies, environmental groups, and other interested parties.

175 Mary Ellen Kustin, Trump Allows Coal Companies To Take Taxpayers For A Ride, Opens Up Mining On Public Lands, THINK PROGRESS (Mar. 28, 2017), https://thinkprogress.org/trump-oks-morecoal-mining-on-public-lands-6ef0d8769be4/. At the second meeting of the committee, the group voted to recommend significantly reducing royalty rates for offshore oil and gas production, urged increased drilling in the Arctic Wildlife Refuge, and suggested further streamlining of environmental review processes. Jennifer A. Dlouhy, U.S. Advisory Panel Pushes for Lower Offshore Oil Royalties, BLOOMBERG (Feb. 28, 2018), https://www.bloomberg.com/news/articles/2018-02-28/lower-offshore-oilroyalties-urged-by-u-s-advisory-panel. 
The Trump Administration, by contrast, quickly and without any additional public involvement decided to end the environmental review process and revoke the moratorium. ${ }^{176}$ The Trump Administration was able to take advantage of reports and processes conducted under the Obama Administration, but those reports were largely not written with the idea that coal leasing would continue during the review process and, therefore, some of the estimates on impacts may not have been adequate.

The central disagreement between the two administrations seems to focus on whether consideration of health and environmental impacts of coal should be included in a review of the program, and whether it makes sense to continue issuing leases that no one really thinks are fair. A problem with lifting the moratorium now is that it keeps the current royalties at the levels set over thirty years ago during the last review.

The approach of the Trump Administration is questionable in light of the struggling coal industry, his campaign promises to promote coal at all costs, and his decision not to consult with environmental interests. This shift is accompanied by rhetoric from the Administration denouncing bureaucracy and promoting more local management and decision-making regarding natural resources. If the Trump Administration is working based on a philosophy that states should be able to make decisions regarding their resources, it would make sense to give the states a larger role in the decision of when and where coal leases are granted. Perhaps the Administration is assuming states simply want immediate monetary returns and, therefore, increased coal leasing at all levels is fulfilling state goals even if not directly conveying control to states. ${ }^{177}$ Seen in that lens, the choice to reduce bureaucracy is coincident with the view of a federalism that minimizes federal involvement and recognizes stronger ideas of state autonomy.

While federalism and reduced bureaucracy may serve as the external justifications of Trump policies, that rationale can be hard to reconcile with a decision-making process (and result) that benefits a very small sectorowners of coal operations. The recent moves from the Department of the Interior with both the Zinke Order and the coal-leasing advisory committee suggest the Department is running more like a company, setting profit maximization over other goals. Voters need to consider whether that is the

176 The rapid Trump administration process may make the new rules more susceptible to challenge because under the Administrative Procedure Act, an agency must show a reasoned basis for policy changes. The Fund for Animals v. Norton, 294 F. Supp. 2d 92, 105 (D.D.C. 2003).

177 The reasoning here may be a bit difficult to parse as all current and previous reports agree that the United States (and the states who share in the returns) is receiving well below the value of the resource. Delaying or pausing the issuance of coal leases would hopefully lead to leases issued under more favorable conditions. But stakeholders need to decide whether they favor getting the maximum return currently available or waiting for a process that might ultimately increase their returns. Coal mining states seem to be lobbying for the former. 
right goal, and lawyers should consider whether such an approach aligns with federal law. ${ }^{178}$

If one agrees that profit maximization is the proper goal for the nation's coal leasing and federal lands programs, one should still investigate whether the methods currently being employed by the Department of the Interior are likely to reach that goal. The Interior Department's approach for re-assessing the leasing rates appears to be centered on the coal-leasing advisory committee. Yet, the advisory committee does not include a large variety of voices, is (as its name implies) merely advisory, and is only required to meet twice a year. ${ }^{179}$ Even members of the committee do not believe that the Trump Administration is giving it much attention or respect.

Outside the Royalty Committee, there may be some internal processes occurring that the public has not been privy to. Statements by the Trump Administration, however, suggest that the economic accounting will not be looking at the full economic costs of the activity. ${ }^{180}$ For a coal company extracting coal from public land, the narrower view of accounting for fair market value may be a promising venture. A close look at which arrangements will yield the highest royalties might also look good to state authorities, who will share in the royalty payments without having any of the burdens of being a land manager or owner. But as the holder of the land, the federal government should use a different calculus that also considers other features like opportunities lost, ability to recover the land, and other issues including contamination, protection of historic and cultural sites, waste management, and water quality. Indeed, the BLM should consider coal-

178 A report from the New York Times argues that the changes and reversals of the Trump Administration can often be tied directly to oil, coal, and gas companies along with other industry groups, seeming to indicate that the Trump Administration views such groups as an important constituency whose interests should be reflected in administration policy. The Trump Administration has closer relationships with industry and energy groups than any previous president. Former EPA Director Pruitt met with them almost daily. Nadja Popovich et al., 67 Environmental Rules on Their Way Out Under the Trump Administration, N.Y. TIMES (Jan. 31, 2018), https://www.nytimes.com/interactive/2017/10/05/climate/trump-environment-rules-reversed.html.

179 Although it appears they will meet quarterly. They first met on October 4, 2017 and then again on February 28, 2018. Press Release, Readout of the First Meeting of Re-chartered U.S. Interior Royalty Policy Committee, U.S. DEP'T OF THE INTERIOR (Oct. 4, 2017), https:/www.doi.gov/pressreleases/readout-first-meeting-re-chartered-us-interior-royalty-policycommittee; Dlouhy, supra note 175.

180 See, e.g., Peter Fairley, States Are Using Social Cost of Carbon in Energy Decisions, Despite Trump's Opposition, INSIDE CLIMATE NEWS (Aug. 14, 2017), https://insideclimatenews.org/news/11082017/states-climate-change-policy-calculate-social-cost-carbon (describing the Trump Administration's opposition to accounting for carbon emissions in policy decisions); Meredith Fowlie \& Mazimilian Auffhammer, Why Rick Perry's Proposed Subsidies For Coal Fail Economics 101, CONVERSATION (Oct. 8, 2017), http://heconversation.com/why-rick-perrysproposed-subsidies-for-coal-fail-economics-101-83339 (describing Energy Secretary Rick Perry's unusual view of coal mining as having positive instead of negative externalities). 
leasing operations in the context of its overarching agency mandate to protect natural resources. ${ }^{181}$

Beyond the coal-leasing program, the Trump Administration is also adopting other policies to expand the extraction of coal and fossil fuels on federal lands. One way it is doing so is by opening up lands that had been declared off limits for coal extraction in previous administrations. For example, desire for additional available land for fossil fuel extraction appears to be one of the driving motivations behind the Administration's efforts to reduce the size of national monuments. ${ }^{182}$ On December 4, 2017, Trump declared that he would reduce Bears Ears National Monument by $85 \%$ and Grand Staircase-Escalante National Monument by nearly $46 \% .{ }^{183}$ At a rally announcing the decision, Trump couched the change in policy as a response to local needs and interests, stating: "They don't know your land, and truly, they don't care for your land like you do." ${ }^{184} \mathrm{He}$ identified the "they" in his sentence as "a small handful of very distant bureaucrats located in Washington" who control the natural resources of Utah under the previous framework. ${ }^{185}$ On February 2, 2018, the shrinkage of the monuments officially occurred and formerly protected lands are now open to new mining claims. ${ }^{186}$ While it is not clear whether there will be many applications for permits or leases on these lands, the Utah BLM office has begun preparing maps and information for those who are interested in exploring the mineral potential of the lands. ${ }^{187}$ The Utah Division of Oil, Gas, and Mining had not received any applications as of February 8, 2018 and doesn't anticipate new claims "anytime soon." 188

18143 U.S.C.A. § 1701(a)(8) (West 2017) ("the public lands [are to] be managed in a manner that will protect the quality of the scientific, scenic, historical, ecological, environmental, air and atmospheric, water resources, and archaeological values...”); id. at § 1732(b) (requiring the prevention of "unnecessary or undue degradation of the lands").

182 This parallels efforts to withdraw from previously negotiated plans to protect the sage grouse, whose wide range unfortunately overlaps with lands that may not be attractive for hydrofracking. See Bret Birdsong, The Grid and the Grouse: Cooperative Federal-State Conservation Planning in the Ages of Obama and Trump, 13 FIU L. REV. 103, 115-26 (2018).

183 Josh Dawsey \& Julet Eilperin, Trump Shrinks Two Huge National Monuments in Utah, Drawing Praise and Protests, WASH. POST (Dec. 4, 2017), https://www.washingtonpost.com/politics/trump-scales-back-two-huge-national-monuments-in-utahdrawing-praise-and-protests/2017/12/04/758c85c6-d908-11e7-b1a8-62589434a581_story.html.

184 Id.

185 Id.

186 Timothy Cama, Trump's National Monument Rollbacks Take Effect, HiLl (Feb. 2, 2018), http://thehill.com/policy/energy-environment/372007-trumps-national-monument-rollbacks-take-effect.

187 Id

188 Josh Siegel, Bears Ears Gets No Mining Applications, WASH. EXAMINER (Feb. 8, 2018), $\mathrm{http}: /$ www.washingtonexaminer.com/bears-ears-gets-no-mining-applications/article/2648556. It seems likely that uranium, not coal, will be the natural resources exploited in the area. Id. 
The Renewable Energy Zones in the California and Arizona deserts are also at risk. ${ }^{189}$ As part of several studies, a long public process, and stakeholder negotiations, the BLM established renewable energy zones where solar energy development would be promoted and facilitated on federal lands with other areas set aside for habitat conservation. ${ }^{190}$ The Trump Administration has announced its intention to change some of the terms of the deal and now allow mining on some of the lands targeted for solar development. ${ }^{191}$ Solar development and coal mining will not be able to coexist.

The North Bering Sea example is also an interesting one. On December 9, 2016, President Obama issued an order seeking to protect the Bering Sea; the stated goal of the Obama Policy was to conserve arctic biodiversity, tribes, climate, and economy of the area. ${ }^{192}$ The policy sought to do so by enhancing the resilience, and particularly the climate resilience, of the area. ${ }^{193}$ Obama had invoked section 12(a) of Outer Continental Shelf Leasing Act allowing the president to "withdraw from disposition any of the unleased lands." 194 Such withdrawal prevents consideration of the area for future oil and gas leasing. ${ }^{195}$ The Trump Administration quickly took aim at this Obama policy to open more areas up to energy extraction as part of his America First Offshore Energy Strategy. ${ }^{196}$

One way to think about these changes is to say that before the current Administration, we had a broader sense of who the public was in public lands.

189 Scott Streater, BLM Proposal Would Revive Mining in Renewable Energy Zone, E\&E News (Oct. 5, 2017), https://www.eenews.net/stories/1060062795.

190 For detail on the Desert Renewable Energy Conservation Plan, which is also currently at risk, see Amy Wilson Morris \& Jessica Owley, Mitigating the Impacts of the Renewable Energy Gold Rush, 15 Minn. J.L. SCI. \& TeCH. 293 (2014); Sammy Roth, In Stunning Reversal, Trump Could Open California Desert to More Solar and Wind Farms, DESERT SUN (Feb. 2, 2018), https://www.desertsun.com/story/news/environment/2018/02/01/trump-could-open-california-desertmore-solar-and-wind-farms-mining-off-roading/1087021001/; Birdsong, supra note 182, at 114-17.

191 Streater, supra note 189.

192 Executive Order, Northern Bering Sea Climate Resilience, Exec. Order 13754, 81 Fed. Reg. 240 (Dec. 14, 2016); Fact Sheet: White House Announces Actions to Protect Natural and Cultural Resources in Alaskan Arctic Ocean, AM. Presidency Project (Dec. 9, 2016), http://www.presidency.ucsb.edu/ws/?pid=122606.

193 Northern Bering Sea Climate Resilience Area, OCEANA, http://usa.oceana.org/northernbering-sea-climate-resilience-area (last visited Mar. 6, 2018).

19443 U.S.C.A. § 1341(a) (West 2014).

195 NAT. Res. Def. COUNCIL \& EARTHJUSTICE, BRIEFER ON PRESIDENTIAL WithdRAWAL UNDER OCSLA SEC. 12(A) 1 (2016), https://www.nrdc.org/resources/briefer-presidential-withdrawal-underoscla-sec-12a (download the PDF using the link on the right side menu, labelled "Downloads") (last visited Feb. 23, 2018).

196 Diana Hacker, Trump Issues Executive Order Revoking Northern Bering Sea Protection and Tribal Participation, Nome NuggeT (May 5, 2017), http://www.nomenugget.com/news/trump-issuesexecutive-order-revoking-northern-bering-sea-protection-and-tribal-participation. 
The government's role is to protect the public lands on behalf of all of the people of the nation including those not yet born. The current Administration is shifting that in two ways. One way is a traditional republican approach that reflects a change in political philosophy_devolving more decision-making power to the states. Indeed, this even includes conveying some land to the states. It also includes opening public land to use by private individuals (e.g., grazing), increasing royalties to states, and working more with the states on what their desires for the land and resources might be. While not everyone will agree that the states should play a more prominent role in federal land policy, (shifting the idea of "public" from the whole country to those geographically linked to the actual land at issue), it is a consistent and defendable political choice. Unfortunately, the Trump Administration also seems to be privileging another category-business interests. Opening up land to greater resource extraction in many places is benefiting the energyproducing industries that have supported him without providing added advantage to the people in the region. The enactment of policies beneficial to the coal industry occurs alongside rules that harm coal communities, including removing funding for remediation of abandoned mines in the President's budget proposals ${ }^{197}$ allowing dumping of debris into nearby streams, ${ }^{198}$ canceling a requirement that oil and gas companies report on methane emissions, ${ }^{199}$ and approving controversial pipelines despite local protests and documented spills. ${ }^{200}$

These policies that seem to privilege very few and both hurt community members and diminish public resources leave one to question: who is President Trump defining as America when he promises to put the country and the people first?

197 Office of Mgmt. \& Budget, America First: A Budget Blueprint to Make AmericA $\begin{array}{llll}\text { GREAT AGAIN } & 27 & \text { (2018), }\end{array}$ https://www.whitehouse.gov/sites/whitehouse.gov/files/omb/budget/fy2018/2018_blueprint.pdf.

198 Jeremy Deaton, Congress is Set to Overturn the Stream Protection Rule, THINK PROGRESS (Jan. 31, 2017), https://thinkprogress.org/congress-is-set-to-overturn-the-stream-protection-rule1829c522f388/\#.gixqd6viv.

199 Popovich et al., supra note 178.

200 Mayra Cuevas \& Steve Almsay, Keystone Pipeline leaks 210,000 Gallons of Oil in South Dakota, CNN (Nov. 17, 2017), https:/www.cnn.com/2017/11/16/us/keystone-pipeline-leak/index.html; Elise Labott \& Jeremy Diamond, Trump Administration Approves Keystone XL Pipeline, CNN (March 24, 2017), https://www.cnn.com/2017/03/23/politics/keystone-xl-pipeline-trump-approve/index.html. 